\title{
Klaoničko iskorištenje i kvaliteta mesa kopuna hibridne linije Hubbard tovljenih hranom obogaćenom glinom
}

Damir Alagić1, Lidija Kozačinski², Tatjana Tušek'1, Željka Cvrtila², Đurica Kalember', Jelka Pleadin ', Marijana Vrbančić', Marija Meštrović', Dejan Marenčić', Vedran Nervo'

Originalni znanstveni rad

\section{SAŽETAK}

U radu je istraživan učinak hrane obogaćene glinom ("GMO free", Fanon d.o.o.) na količinu i kakvoću mesa kopuna. Rezultati istraživanja ukazuju na visok randman i visok udio najvrjednijih dijelova trupa (prsa, batak, zabatak). Kemijskom analizom utvrđen je u uzorcima mesa kopuna udio vode od 71,94\%, bjelančevina 19,76\%, masti 6,67\% i pepela 1,20\%, dok su najzastupljenije masne kiseline bile oleinska $(40,74 \%)$, palmitinska $(30,15 \%)$ i stearinska $(11,30 \%)$.

Ključne riječi: meso kopuna, klaoničko iskorištenje, osnovni kemijski sastav, masnokiselinski profil

\section{UVOD}

U današnje vrijeme meso peradi je prvi izbor većine potrošača jer posjeduje visoku nutritivnu vrijednost, lako je probavljivo s izrazito visokim udjelom bjelančevina povoljnog aminokiselinskog sastava. No pri tome se, posve neopravdano, meso kopuna veoma rijetko ili uopće ne nalazi u maloprodaji, iako se, istina u regionalnim okvirima, u našoj zemlji proizvodilo i konzumiralo kao poseban specijalitet. Kvalitetu ovog mesa znali su cijeniti i stari narodi 2000 godina pr. Kr. te se nerijetko kopun nalazio na stolu egipatskih faraona, kineskih careva i indijskih maharadža (Ljubinković, 2002.). Kopuni su posebno uzgojeni pjetlići, kopunizirani (kastrirani) u dobi od 6-8 tjedana, izrazito kvalitetnoga mesa. Uklanjanjem sjemenika smanjuje se produkcija muških spolnih hormona, a time se mijenjaju i spolni refleksi i kopun mijenja svoje pona- šanje. Postaje manje aktivan, energiju koju obično troše, pijetlovi, na međusobne borbe, teritorijalno ponašanje i dr. uvelike se smanjuje i dovodi do učinkovite pretvorbe hrane u rast, taloženje masti i poboljšanje kvalitete mesa (Jacob i Mather, 2000., Tušek i sur., 2004.).

Uzgoj kopuna je vrlo čest u malim farmama širom svijeta, ali proizvodnja mesa od kopuna, kao komercijalnog proizvoda, održava se samo u zemljama s tradicijom takve proizvodnje kao što su Francuska, Italija, Mađarska i Španjolska (Syemeon i sur. 2012.). Konzumacija ovog mesa ima i blagdanski karakter (Božić) pa se primjerice u Španjolskoj kopuni uzgajaju do životne dobi od 8 mjeseci (Diaz i sur., 2010.), dok se proizvodnja u sjeverozapadnoj Španjolskoj procjenjuje na oko 2000 komada na godinu (Diaz i sur., 2010.). Procjene za SAD-e su oko jedan milijun komada na godinu (Jacob i Mather, 2000.).

\footnotetext{
1 Dr. sc. Damir Alagić, prof.v.š.; Dr. sc. Tatjana Tušek, prof.v.š.; Mr. sc. Đurica Kalember, v. pred.; Marijana Vrbančić, mag. ing. agr., pred.; Marija Meštrović, dipl. ing., v. pred., Dr. sc. Dean Marenčvet.ić, prof. v. š.; Vedran Nervo, dr. med. vet., pred.: Visoko gospodarsko učilište u Križevcima, M. Demerca 1, Križevci

2 Dr. sc. Lidija Kozačinski, redoviti profesor; dr. sc. Željka Cvrtila, redoviti profesor; Sveučilište u Zagrebu, Veterinarski fakultet, Zavod za higijenu, tehnologiju i sigurnost hrane. Heinzelova 55, Zagreb

3 Dr. sc. Jelka Pleadin, izvanredni profesor; Hrvatski veterinarski institut, Laboratorij za analitičku kemiju, Savska c. 143, Zagreb
} 
Meso peradi interesantno je potrošačima i zbog činjenice da nije opterećeno vjerskim predrasudama (Nemanič i Berić, 1995.), a proizvodnja kopuna zanimljiva je i zbog kratkog tova, dobre konverzije hrane uz veliku izlaznu masu u usporedbi s proizvodnjom mesa drugih vrsta životinja te ekonomskih pokazatelja tova kopuna koji su izrazito pozitivni (Firšt-Godek i sur., 2004.).

Ovo je istraživanje obuhvatilo utvrđivanje kvalitete mesa kopuna te izlazne tovne mase i randman kopuna i kokoši hibridne linije Hubbard, hranjenih GMO free hranom uz dodatak gline.

\section{MATERIJAL I METODE}

Pokusno razdoblje hranidbe hibridne linije Hubbard provedeno je od svibnja do rujna 2016. godine.
A

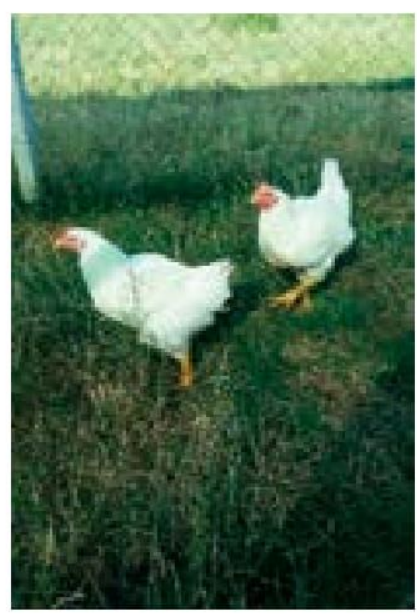

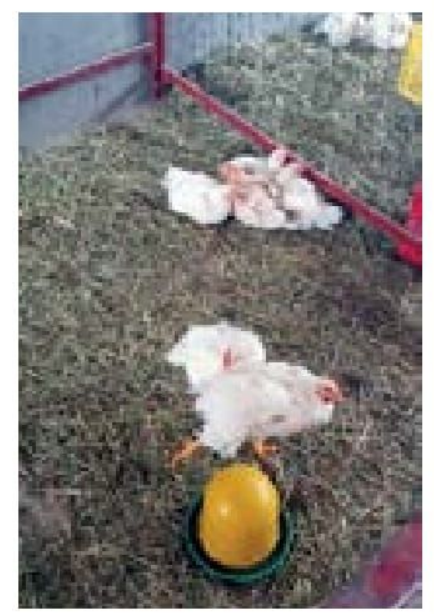

B
Slika 1. Kopuni na ispustu i u boksu (Nervo, 2016.)

A) Kopuni hibridne linije Hubbard na ispustu

B) Kopuni hibridne linije Hubbard, u boksu 24 sata nakon kopunizacije

Od tvrtke "Pravi ritam" koja posreduje u nabavi jednodnevnih pilića iz valionice "Gallus" (Mađarska) preuzeto je 60 jedinki neseksiranih jednodnevnih pilića hibridne linije Hubbard. Hranjeni su ad libitum peletiranom "GMO free" hranom, poduzeća "FANON d.o.o.", Petrijanec, i to kompletnom smjesom (I. - IV.) za hranidbu tovnih pilića. Hibridi su tovljeni 16 tjedana u proljetno - ljetnom razdoblju, držani podno s ispustom od $27 \mathrm{~m}^{2} \mathrm{u}$ Peradarskom praktikumu Visokog gospodarskog učilišta u Križevcima.

\section{Kopunizacija (kastracija) pjetlića}

$\mathrm{U}$ dobi od 6 do 7 tjedana 25 pjetlića je kopunizirano (pokusna grupa), a 24 kokoši (kontrolna grupa) i dva pijetla su ostavljeni za edukativne potrebe Peradarskog praktikuma Učilišta. Kopuniziranje je obavljeno na jedinkama metodom po Dietzu i sur.
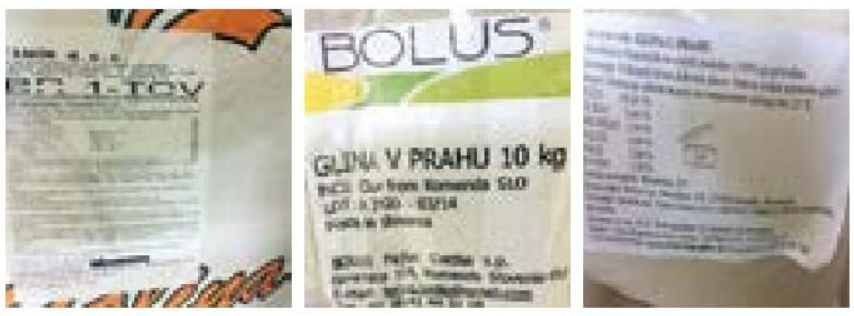

Slika 3. Fanon gotova smjesa za hranidbu peradi i bolus glina kao dodatni izvor minerala

(1981.) kojima je prethodno uskraćena hrana 72 sata (Alagić i sur., 2004.).

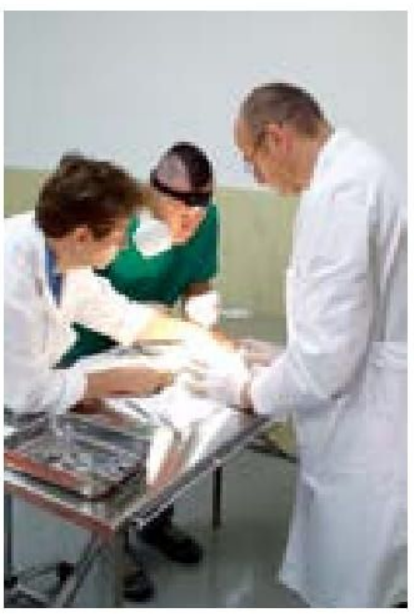

a)

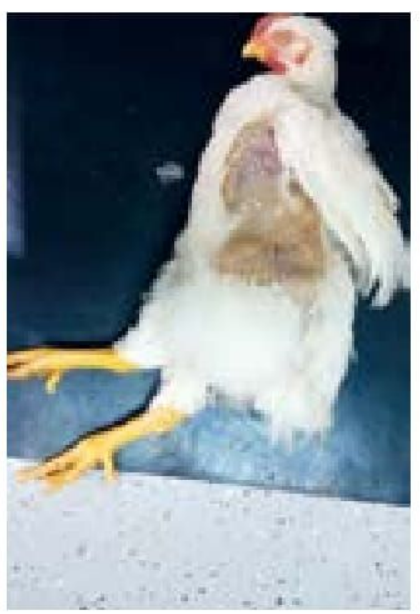

c)

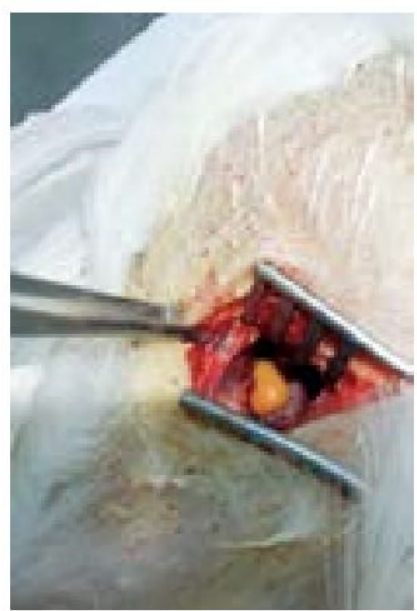

b)

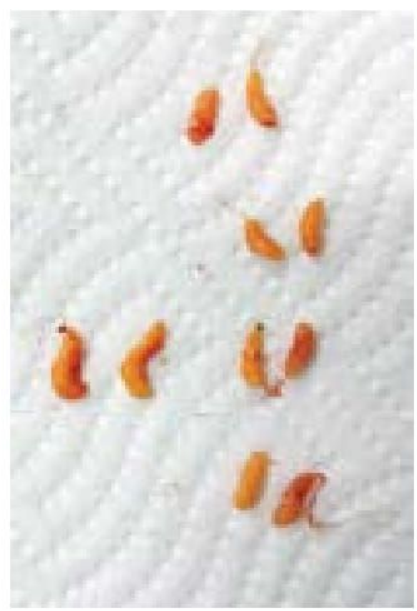

d)
Slika 2. Kopunizacija pjetlića (Nervo, 2016.)

a) Operativni zahvat (kopunizacija) na anesteziranom pjetliću hibridne linije Hubbard

b) Prikaz lijevog sjemenika u trbušnoj šupljini pjetlića c) Kopunizirani pjetlić i mjesto otvaranja trbušne šupljine

d) Izvađeni sjemenici pjetlića

Tijekom tova kopuna i pjetlića obavljeni su svi preventivni zahvati zdravstvene zaštite propisa- 
ni Zakonom o veterinarstvu (NN R.H. br. 70/97, 105/01,172/03 te bakteriološka pretraga izmeta na bakterije roda Salmonella prije klanja. Tov, kopunizacija i klanje kopuna je bilo u skladu s Uredbom Komisije (EZ) 543/2008 od 16. lipnja 2008. godine (MS1).

\section{Klaonička obrada}

Klaonička obrada je obavljena u registriranom objektu "Viki d.o.o." Reka, uz obavezni veterinarski pregled službenog veterinara kontrolnog tijela, Veterinarske stanice Koprivnica.

Pri dolasku u klaonički objekt, prosječna masa kopuna iznosila 4,9 kg ( $\mathrm{N}=17)$, a kokoši $4,5 \mathrm{~kg}$ ( $\mathrm{N}$ = 21). Ukupno je utrošeno 600 kg "GMO free" hrane/105 dana i 75 kg kukuruzne prekrupe / 17 dana te $1,5 \mathrm{~kg}$ gline za cijelo razdoblje tova.

\section{Senzorna pretraga}

Odmah nakon dopreme uzoraka u laboratorij obavIjena je senzorna pretraga. U tu svrhu korištena je metoda sustava bodovanja (Bruna i sur., 2001; lucci i sur., 2007; Kovačević i sur., 2009.). U panelu je sudjelovalo 10 ocjenitelja. Najveći mogući ostvareni broj bodova u senzoričkoj pretrazi iznosi 190 i to za izgled 1 bod, za boju i izgled presjeka 4 boda, konzistenciju i miris po 3 te okus proizvoda maksimalno može biti ocijenjen s 8 bodova.

\section{Kemijska analiza mesa kopuna}

Nakon hlađenja mesa na temperaturi od $+4{ }^{\circ} \mathrm{C}$ uzorci mesa prsnog mišićja dostavljeni su u prijenosnom hladnjaku na Veterinarski fakultet Sveučilišta u Zagrebu u Zavod za higijenu, tehnologiju i sigurnost hrane gdje je utvrđen osnovni kemijski sastav uzoraka mesa kopuna te senzorička pretraga.

Analiza osnovnog kemijskog sastava obuhvatila je određivanje vode, bjelančevina, masti i pepela postupcima utvrđenima ISO normama:

- određivanje sadržaja vode - ISO 1442:1997 (Meso i mesni proizvodi - Određivanje sadržaja vlage),

- određivanje sadržaja bjelančevina - HRN ISO 937:1999 (Meso i mesni proizvodi - Određivanje količine dušika),

- određivanje ukupne masti - HRN ISO 1443:1999 (Meso i mesni proizvodi - Određivanje ukupne količine masti),

- određivanje pepela - ISO 936:1998 (Meso i mesni proizvodi - Određivanje ukupnog pepela).

Analizirano je ukupno 10 uzoraka mesa kopuna, a rezultati su prikazani kao srednja vrijednost.

\section{Određivanje masnokiselinskog sastava}

Masnokiselinski sastav utvrđen je u Laboratoriju za analitičku kemiju Hrvatskog veterinarskog instituta u Zagrebu. Metilni esteri masnih kiselina pripremljeni prema metodi opisanoj u istraživanju Lešić i sur. (2017.), analizirani su plinskom kromatografijom na plinskom kromatografu 7890B (Agilent Technologies, SAD) sa split/splitless injektorom $\left(270^{\circ} \mathrm{C}\right)$, plameno-ionizacijskim detektorom $\left(280^{\circ} \mathrm{C}\right)$ i kapilarnom kolonom DB-23 dužine $60 \mathrm{~m}$, promjera $0,25 \mathrm{~mm}$ te debljine sloja nepokretne faze 0,25 $\mu \mathrm{m}$. Uzorak $(1 \mu \mathrm{L})$ je injektiran uz omjer razdjeljenja 1:50. Početna temperatura kolone podešena je na $130^{\circ} \mathrm{C}$, nakon 1 minute programirano je povećavana brzinom od $6,5^{\circ} \mathrm{C} / \mathrm{min}$ do $170^{\circ} \mathrm{C} / \mathrm{min}$, zatim je brzinom od $2,75^{\circ} \mathrm{C} / \mathrm{min}$ grijana do $215^{\circ} \mathrm{C}$ uz zadržavanje od 12 minuta, nakon toga se ponovno brzinom od $40^{\circ} \mathrm{C} / \mathrm{min}$ zagrijavala do $230^{\circ} \mathrm{C}$ uz zadržavanje od 3 minute. Plin nosioc bio je helij uz protok od $43 \mathrm{~cm} / \mathrm{s}$ (konstantni tlak), detektorski protoci vodika i zraka bili su $40 \mathrm{~mL} / \mathrm{min}$ te $450 \mathrm{~mL} / \mathrm{min}$, a kao makeup plin korišten je dušik s protokom od $25 \mathrm{~mL} / \mathrm{min}$. Metilni esteri masnih kiselina identificirani su usporedbom s vremenima zadržavanja 37 metilnih estera masnih kiselina standardne smjese (SupelcoTM 37 Component FAME Mix, Bellefonte, Pennsylvania, SAD) analizirane pri istim uvjetima. Rezultati masokiselinskog sastava su prikazani kao postotak od ukupnih masnih kiselina.

\section{REZULTATI I RASPRAVA}

Kopuni ( $N=17)$ ukupne izlazne mase žive vage 82,5 kg i kokoši $(\mathrm{N}=21)$ ukupne izlazne mase žive vage 94 kg upućeni su na klanje u registrirani klaonički objekt pod veterinarskim nadzorom. Na liniji klanja iskrvarenje je bilo dobro, a tijekom veterinarskog pregleda nisu uočene patološke promjene trupova ili organa. Na mjestima kopunizacije, jedva su vidljive tanke bijele linije na površini kože trupova kopuna, bez priraslica ili vidljivih promjena na unutrašnjim dijelovima trupa.

U tablici 1. prikazani su usporedni rezultati tovne mase i randmana kopuna i kokoši.

Kao što je vidljivo iz rezultata u Tablici 1., prosječna masa žive vage kopuna iznosila je $4,85 \mathrm{~kg}$, ukupna masa nejestivih dijelova trupa za kopune (glave, noge, utroba i perje) iznosila je 20,2 kg dok je ukupna masa jestivih dijelova trupa iznosila $62,3 \mathrm{~kg}$, a jestivih iznutrica $4,0 \mathrm{~kg}$ (jestive iznutrice i vratovi).

$\mathrm{U}$ istoj tablici navedene su izlazne tovne mase i randman za kokoši. Prosječna masa žive vage kokoši iznosila je 4,5 kg. Ukupna masa nejestivih dijelova trupa za kokoši iznosila je 26,2 kg dok je uku- 
Tablica 1. Izlazne tovne mase i randman

\begin{tabular}{|c|c|c|c|c|c|c|c|}
\hline $\begin{array}{c}\text { Kategorija } \\
\text { peradi }\end{array}$ & $\begin{array}{c}\text { Masa žive } \\
\text { vage (kg }\end{array}$ & $\begin{array}{c}\text { Ukupno } \\
\text { jestivih } \\
\text { dijelova trupa } \\
\text { (kg) }\end{array}$ & $\begin{array}{c}\text { Masa jestivih } \\
\text { trupova (kg) }\end{array}$ & $\begin{array}{c}\text { Ukupno } \\
\text { jestivih } \\
\text { iznutrica (kg) }\end{array}$ & $\begin{array}{c}\text { Ukupno } \\
\text { nejestivih } \\
\text { dijelova trupa } \\
\text { (kg) }\end{array}$ & $\begin{array}{c}\text { Randman } \\
\text { svih jestivih } \\
\text { dijelova trupa }\end{array}$ & $\begin{array}{c}\text { Randman } \\
\text { jestivih } \\
\text { trupova (\%) }\end{array}$ \\
\hline Kopuni (n=17) & 82,5 & 62,3 & 58,3 & 4,0 & 20,2 & 76 & 71 \\
\hline Kokoši (n=21) & 94,0 & 53,1 & 49,4 & 3,7 & 26,2 & 67 & 62 \\
\hline Sveukupno & 176,5 & 115,4 & 107,7 & 7,7 & 46,4 & - & - \\
\hline
\end{tabular}

pna masa jestivih dijelova trupa iznosila 53,1 kg, a jestivih iznutrica 3,7 kg (jestive iznutrice i vratovi).

Randman kopuna hibridne linije Hubbard od $76 \%$ razlikuje se od randmana mesa kopuna hibridne linije Ross-308, koji je veći i iznosi 86,6\% prema rezultatima istraživanja Mandić i sur. (2005.). Kako je riječ o različitom genetskom materijalu, različitoj kvaliteti hrane, klaoničkoj obradi i dr., a samo su dužina tova, vrijeme i metoda kopunizacije bili jednaki, rezultati se mogu samo djelomično uspoređivati.

Rezultati senzorne pretrage prikazani su u Tablici 2.

Tablica 2. Rezultati senzorne pretrage mesa kopuna

\begin{tabular}{|l|c|c|}
\hline Pokazatelji & $\begin{array}{c}\text { Najveći mogući } \\
\text { broj bodova }\end{array}$ & $\begin{array}{c}\text { Ocijenjeni broj } \\
\text { bodova }\end{array}$ \\
\hline Izgled & 1,00 & 0,96 \\
\hline $\begin{array}{l}\text { Boja i izgled } \\
\text { proizvoda }\end{array}$ & 4,00 & 3,68 \\
\hline Konzistencija & 3,00 & 2,86 \\
\hline Miris & 3,00 & 2,76 \\
\hline Okus & 8,00 & 7,61 \\
\hline$\Sigma$ & $\mathbf{1 9 , 0 0}$ & $\mathbf{1 7 , 8 7}$ \\
\hline
\end{tabular}

Uzorci mesa kopuna u okviru senzorne pretrage polučili su vrlo dobre i visoke ocjene. Od ukupnih 19,00 bodova respektabilnih 17,87 bodova. Najbolje je ocijenjen izgled, gdje je od ukupnog 1,00 boda ostvaren čak 0,96 bod.

U senzornoj pretrazi mesa kopuna utvrđena je svijetložuta boja kože slično kao i kod dobro uhranjenih brojlera. Boja mesa bila je svijetlo - ružičasta s nešto svjetlijim mesom bataka i zabataka u odnosu na drugu perad što se vjerojatno može opisati raspodjelom masnoće $u$ trupu. Mišićno tkivo kopuna bilo je obilato razvijeno osobito na prsima, batacima i zabatacima, ali bez izdvojenih nakupina masnog tkiva. Mnogi autori također ističu da je meso kopuna nježnije, sočnije i ukusnije od piletine (Mast i sur., 1981.; Tor i sur., 2005.).

Meso kopuna imalo je specifičnu aromu, gotovo bez mirisa krvi i užeglosti. U probi pečenja meso je bilo mekoelastične konzistencije, ugodne teksture i izrazito sočnog okusa koji se razvija tijekom žvakanja.

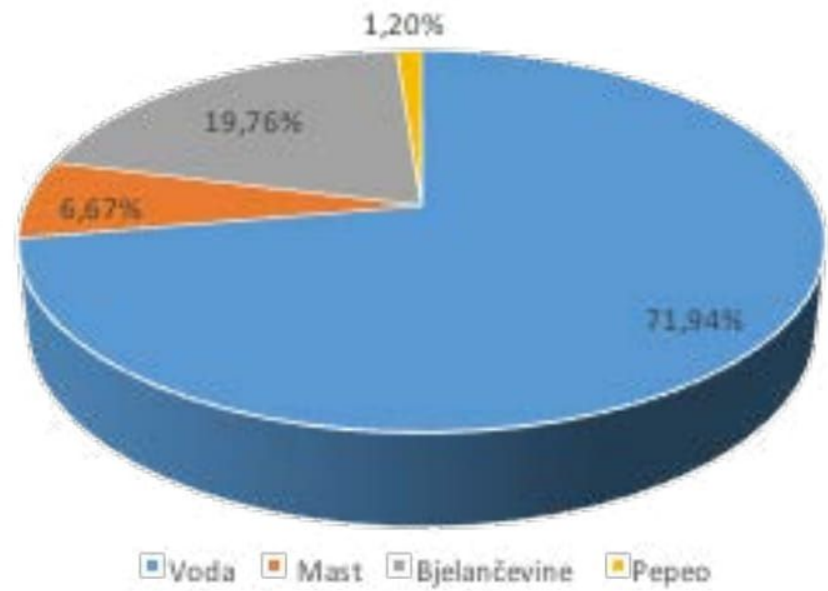

Grafikon 1. Kemijski sastav mesa kopuna

Prosječna količina vode u uzorcima iznosila je $71,94 \%$, bjelančevina $19,76 \%$, masti $6,67 \%$ a pepela $1,20 \%$. Ako dobivene rezultate usporedimo s rezultatima ranijih istraživanjima u kojima je utvrđivan kemijski sastav mesa kopuna i pijetlova (Mandić i sur., 2005.; Tor i sur., 2005.) vidljiva je razlika u količini masti, no još uvijek u korist kopuna. Poznato je da je masnoća kod kopuna inter - i intramuskularno raspoređena, a koncentracija joj je u bijelom i tamnom mesu veća u odnosu na nekopunizirane životinje, što utječe na sočnost i konzistenciju mesa u smislu mekoće (Jacob i Mather, 2000.). Tome doprinosi i smanjeni udio bjelančevina u usporedbi s mesom pijetlova što se posljedično očituje izraženom tvrdoćom i suhoćom mesa pijetlova. Kod pijetlova je masno tkivo uglavnom raspoređeno kao potkožno masno tkivo što također ne doprinosi poboljšanju konzistencije. Ovdje svakako treba naglasiti da meso kopuna u usporedbi s drugim vrstama peradi ima prosječno visok udio bjelančevina. To doprinosi specifičnom okusu i mirisu mesa kopuna, koji se razlikuje od mesa ostale peradi (Mandić i sur., 2005.).

Iz rezultata prikazanih u tablici 3. vidljivo je da su najzastupljenije masne kiseline u mesu kopuna oleinska $(40,74 \%)$, palmitinska $(30,15 \%)$ i stearinska (11,30\%). To je djelomično u skladu s ranijim 
Tablica 1. Profil masnih kiselina u mesu kopuna

\begin{tabular}{|c|c|c|}
\hline Skupina & Masna kiselina & Maseni udio (\%) \\
\hline SFA & $\mathrm{C} 12: 0$ & 0,12 \\
\hline SFA & $\mathrm{C} 14: 0$ & 0,88 \\
\hline MUFA & $\mathrm{C} 14: 1$ & 0,11 \\
\hline SFA & $\mathrm{C} 15: 0$ & 0,09 \\
\hline SFA & $\mathrm{C} 16: 0$ & 30,15 \\
\hline MUFA & $\mathrm{C} 16: 1 \mathrm{n} 7 \mathrm{t}$ & 0,62 \\
\hline MUFA & $\mathrm{C} 16: 1 \mathrm{n} 7 \mathrm{c}$ & 3,70 \\
\hline SFA & $\mathrm{C} 17: 0$ & 0,23 \\
\hline SFA & $\mathrm{C} 18: 0$ & 11,30 \\
\hline MUFA (omega-9) & $\mathrm{C} 18: 1 \mathrm{n} 9 \mathrm{c}$ & 40,74 \\
\hline MUFA (omega-7) & $\mathrm{C} 18: 1 \mathrm{n} 7$ & 2,37 \\
\hline PUFA (omega-6) & $\mathrm{C} 18: 2 \mathrm{n} 6 \mathrm{c}$ & 8,07 \\
\hline PUFA (omega-6) & $\mathrm{C} 18: 3 \mathrm{n} 6$ & 0,27 \\
\hline PUFA (omega-3) & $\mathrm{C} 18: 3 \mathrm{n} 3$ & 0,91 \\
\hline MUFA & $\mathrm{C} 20: 1 \mathrm{n} 9$ & 0,43 \\
\hline
\end{tabular}

SFA=zasićene masne kiseline $/$ Saturated Fatty Acid,

MUFA=jednostruko nezasićene masne kiseline / Monounsaturated Fatty Acid,

PUFA =višestruko nezasićene masne kiseline / Polyunsaturated Fatty Acid

istraživanjima prema kojima su u mesu kopuna u najvećem postotku utvrđene oleinska, palmitinska i linolna kiselina (Amorim i sur., 2016.). Sinanoglou i sur. (2011.) su također naveli da su u ukupnim lipidima kopuna i pjetlića zastupljene oleinska i palmitinska kiselina, ali i linolna i palmitoleinska kiselina. Uspoređujući masnokiselinski sastav mesa pijetlova i kopuna, u mesu kopuna bila je zastupljenija oleinska kiselina, ali su maslačna i starinska značajno manje zastupljene.

U našem istraživanju su analizom masnokiselinskog sastava u skupnom uzorku mesa kopuna dobiveni sljedeći rezultati: SFA 42,77\%, MUFA 47,96\%, PUFA 9,26\%, n-3 0,91\%, n-6 8,35\% te omjer PUFA/ SFA 0,22, a omjer n-6/n-3.

$\mathrm{U}$ zaštićenom EU proizvodu portugalske pasmine kopuna "Capão de Freamunde" (Anon., 2015.), udio MUFA kreće se od 42 do $45,5 \%$, a sadržaj oleinske kiseline od 35,5 do $40 \%$. U odnosu na naše istraživanje, u kopunima je udio MUFA i oleinske kiseline neznatno veći.

Uspoređujući dobivene rezultate masnokiselinskog sastava kopuna s istraživanjima Sinanoglou i sur. (2011.) možemo zaključiti da nema velikih odstupanja. Naši rezultati upućuju na omjer PUFA/ SFA manji od 0,4 a omjer n-6/n-3 utvrđen u našim istraživanjima veći je 6 .

Evolucijski, ljudi su se razvijali konzumirajući hranu koja sadrži dosta nezasićenih masnih kiselina, pogotovo $n-3$ kiselina. Poznato je da je optimalni omjer n-6 i n-3 masnih kiselina 1:1. U prehrani zapadne civilizacije taj je omjer uglavnom poremećen i često je u korist n-6 masnih kiselina. Prema preporukama WHO (2003.) omjer polinezasićenih i zasićenih masnih kiselina (PUFA/SFA) bi se trebao kretati između 0,4 - 1, dok bi se omjer omega- 6 i omega-3 polinezasićenih masnih kiselina $(n-6 / n-3)$ trebao kretati između 1 - 4. S druge, pak, strane "British nutrition foundation" (1992.) navodi omjer n-6/n-3 u intervalu od 4 do 6 . $U$ današnje doba, s obzirom na dostupnost informacija i saznanja o utjecaju hrane na razna oboljenja, potrošačima je masnokiselinski sastav mesa postao važan kriterij prilikom kupovine hrane (Wood i sur., 2003.). U tom smislu predlaže se da masnokiselinski sastav mesa bude osnova prema kojoj će se određivati sastav obroka i tip hranidbe životinja.

\section{ZAKLJUČAK}

Kopuni hibridne linije Hubbard hranjeni hranom obogaćenom glinom klaonički su obrađeni pri prosječnoj masi od 4,9 kg. Udio osnovnih dijelova trupa bio je visok s randmanom od $76 \%$ u odnosu na kokoši (67\%) koje su prosječno bile mase $4,5 \mathrm{~kg}$. U senzornoj je ocjeni meso kopuna ukupno ocijenjeno s 17,87 bodova od mogućih 19,00. U ocjeni konzistencije ocjenjivači su naglasili da je meso kopuna nježnije, a posljedično tome u probi kuhanja i pečenja meso je bilo sočnije i izrazito ukusno. Randman jestivih dijelova trupa kopuna u odnosu na kokoši je veći za $9 \%$.

Analize kemijskog i masnokiselinskog sastava mišića prsiju ukazale su na prihvatljivu kvalitetu mesa kopuna, s obzirom na utvrđeni niski udio masti i visoki udio bjelančevina te veći udio polinezasićenih u odnosu na zasićene masne kiseline. Stoga rezultati ovog istraživanja pokazuju da bi se značajnijom proizvodnjom ovakvog proizvoda visoke prehrambene kvalitete zasigurno obogatila gastronomska ponuda na tržištu. Daljnja istraživanja kvalitete mesa kopuna trebaju biti usmjerena na mogućnost dodatne modifikacije njihove hranidbe, s ciljem postizanja još povoljnijih omjera polinezasićenih i zasićenih masnih kiselina (PUFA/ SFA) te omjera omega-6 i omega-3 polinezasićenih masnih kiselina (n-6/n-3), u skladu sa zdravstvenim preporukama.

\section{Zahvala}

Najljepše se zahvaljujemo

našim sponzorima, poduzećima:

"Viki d.o.o." iz Čakovca,

Klaonička obrada i prerada pilećeg i kokošjeg mesa,

"Fanon d.o.o." iz Petrijanca, Proizvodnja svih vrsta

stočne hrane i distributeru

"TAJNA GLINE - Nedelišče". 


\section{LITERATURA}

Alagić, D., T. Tušek, V. Mandić (2004): Kopunizacija anesteziranih pjetlića. Vet. Stn. 35 (5-6), 273-279.

Amorim, A., S. Rodrigues, E. Pereira, A. Teixeira (2016): Physicochemical composition and sensory quality evaluation of capon and rooster meat. Poult Sci. 95, 5, 1211-1219.

Anonimno (2015): Objava zahtjeva u skladu s člankom 50 stavkom 2. točkom (a) Uredbe (EU) br. 1151/2012 Europskog parlamenta i Vijeća o sustavima kvalitete za poljoprivredne i prehrambene proizvode (2015/C 2/03). Jedinstveni dokument UREDBA VIJEĆA (EZ) br. 510/2006 o zaštiti oznaka zemljopisnog podrijetla i oznaka izvornosti poljoprivrednih i prehrambenih proizvoda (2) "CAPÃO DE FREAMUNDE" EZ br.: PT-PGI-0005-0846-10.1.2011. SI. list EU od 7.1.2015. Ova je objava temelj za podnošenje prigovora na zahtjev u skladu s člankom 51. Uredbe (EU) br. 1151/2012 Europskog parlamenta i Vijeća

British Nutrition Foundation (1992): Task force on unsaturated fatty acids. London. Chapman and Hall.

Bruna, J. M., E. M. Hierro, L. De La Hoz, D. S. Mottram, M. Fernandez, J. A. Ordonez (2001.): The contribution of Penicillium aurantiogriseum to the volatile composition and sensory quality of dry sausages. Meat Sci. 59, 97-107.

Díaz, O., L. Rodríguez, A. Torres, A. Cobos (2010): Chemica composition and physico-chemical properties of meat from capons as affected by breed and age. Instituto Nacional de Investigación y Tecnología Agraria y Alimentaria (INIA) Spanish Journal of Agricultural Research 20108 (1), 91-99

lucci, L., F. Patrignani, N. Belletti, M. Ndagijimana, M. E. Guerzoni, F. Gardini, R. Lanciotti (2007): Role of surfaceinoculated Debaryomyces hansenii and Yarrowia lipolytica strains in dried fermented sausage manufacture. Part 2: Evaluation of their effects on sensory quality and biogenic amine content. Meat Sci. 75, 669-675.

Jacob, J., F. B., Mather (2000): Capons. Department of Animal Sciences, Cooperative Extension Service, Institute of food and Agricultural Sciences, University of Florida.

Ljubinković, S. (2002): Što je kopun? Gospodarski list (1. lipnja, 2002.).

Nemanič, J., Ž. Berić (1995): Peradarstvo. Nakladni zavod globus. Zagreb.

Firšt-Godek, L., T. Tušek, V Mandić, D. Alagić (2004): Analiza troškova u tovu kopuna. Agronomski glasnik 1-2, 13-16.
Mast M.G., H.C. Jordan, J.H. Macneil (1981): The effect of partial and complete caponization on growth rate, yield and selected physical and sensory attributes of cockerels. Poultry Sci 60, 1827 1833.

Kovačević, D., K. Suman, D. Šubarić, K. Mastanjević, S. Vidaček (2009): Investigation of homogeneity and physicochemical characterisation of the Homemade Slavonian Sausage. Meso XI, 338-344.

Lešić, T., S. Kolarić Kravar, G. Krešić, J. Pleadin (2017): Nutritivna kvaliteta masti industrijskih kobasica. Meso 19, 496-503.

Mandić, V., T. Tušek, D. Alagić, V. Podhraški-Pomper, D. Majnarić (2005): Klaoničko iskorištenje i kemijski sastav mesa kopuna. Meso VII, 5, 35-39

Sinanoglou, V.J., F. Mantis, S. Miniadis-Meimaroglou, G.K. Symeon, I.A. Bizelis (2011): Effects of caponisation on lipid and fatty acid composition of intramuscular and abdominal fat of medium-growth broilers. British Poultry Science 52, 3, 310-317.

Symeon, G. K., F. Mantis, I. Bizelis, A. Kominakis, E. Rogdakis (2012.): Effects of caponization on growth performance, carcass composition and meat quality of males of a layer line, Animal (2012), 6:12,2013-2030

Tor, M., J. Estany, A. Francesch, M. D. Cubiló (2005): Comparison of fatty acid profiles of edible meat, adipose tissues and muscles between cocks and capons. Anim. Res. 54, 5, 413-424

Tušek, T., V. Mandić, D. Alagić, M. Meštrović, D. Mihelić (2004): Rezultati tova kopuna hibridne linije Ross-308. Stočarstvo, 58 (2), 95-101.

WHO/FAO (2003): Diet, nutrition and prevention of chronic diseases (p. 148). Report of a Joint WHO/FAO Expert Consultation. Geneva, World Health Organization.

Wood, J. D., R. I. Richardson, G. R. Nute, A. V. Fisher, M. M. Campo, E.,Kasapidou, P. R. Sheard, M. Enser (2003): Effects of fatty acids on meat quality: a review. Meat Science, 66, 21-32.

Mrežna stranica (MS):

MS1- UREDBA KOMISIJE (EZ) br. 543/2008 od 16. lipnja 2008. o utvrđivanju detaljnih pravila za primjenu Uredbe Vijeća (EZ) br. 1234/2007 u pogledu tržišnih standarada za meso peradi, https://eurlex.europa.eu/legaLcontent/HR/TXT/ PDF/?uri=CELEX:32008R0543, 8.11.2018.

Dostavljeno: 17.10. 2018.

Prihvaćeno: 15.11.2018.

\section{Effect of clay feed additives on meat yield and quality of Hubbard capons}

\section{SUMMARY}

The paper examines the meat yield and quality of Hubbard hybrid line capons fed on diet supplemented with clay (GMO free, Fanon d.o.o.). The research results indicated a high meat yield and large share of the most valuable carcass parts (breast, leg, thigh). The chemical analysis showed that capon meat samples contained $71.94 \%$ water, $19.76 \%$ protein, $6.67 \%$ fat and $1.20 \%$ ash, while dominant fatty acids included oleic $(40.74 \%)$, palmitic $(30.15 \%)$ and stearic acid (11.30\%).

Key words: capon meat, meat yield, chemical composition, fatty acid profile 


\section{Schlachtwert und Fleischqualität von Kapaunen der Hybridlinie Hubbard, gemästet mit Futtermitteln mit Zugabe von Tonerde}

\section{ZUSAMMENFASSUNG}

In der Arbeit wurden die Auswirkungen von Futtermitteln, welche mit Tonerde angereichert wurden ("GMO free", Fanon d.o.o), auf die Quantität und die Qualität von Kapaunfleisch untersucht. Die Untersuchungsergebnisse weisen auf einen hohen Ertrag und einen hohen Anteil der wertvollsten Rumpfteile (Brust, Ober- und Unterkeule) hin. Bei einer chemischen Analyse wurden in den Kapaunfleischproben folgende Anteile ermittelt: Wasser 71,94\%, Eiweiß 19,76 \%, Fette 6,67\% und Asche 1,20\%; Fettsäuren: Oleinsäure (40,74\%), Palmitinsäure (30,15\%) und Stearinsäure (11,30\%).

Schlüsselwörter: Kapaunfleisch, Schlachtwert, chemische Zusammensetzung, Fettsäurenprofil

\section{El rendimiento en el matadero y la calidad de la carne de los capones de la línea híbrida Hubbard cebados por el pienso enriquecido en arcilla}

\section{RESUMEN}

En este trabajo fue investigada la influencia del pienso enriquecido en arcilla ("GMO free", Fanon d.o.o) en la cantidad y la calidad de la carne de los capones. Los resultados de la investigación muestran un alto rendimiento y el alto contenido de los mejores partes de capón (pechuga de pollo, pierna de pollo, muslo de pollo). Por el análisis química en las muestras de la carne de capón fueron determinados el contenido del agua de $71,94 \%$, las proteínas $19,76 \%$, las grasas $6,67 \%$ y las cenizas 1,20 \%, mientras los ácidos grasos más comunes fueron el ácido oléico (40,74\%), palmítico $(30,15 \%)$ y esteárico $(11,30 \%)$.

Palabras claves: carne de capón, rendimiento en matadero, composición química básica, perfil de ácidos grasos

\section{Rendimento della macellazione e qualità della carne dei capponi della linea ibrida Hubbard alimentati con mangimi da ingrasso arricchiti con argilla verde}

\section{RIASSUNTO}

Nell'articolo è stato esaminato l'impatto dei mangimi arricchiti con argilla verde ("GMO free", Fanon d.o.o/S.r.I.) sulla quantità e sulla qualità della carne del cappone. I risultati della ricerca hanno evidenziato un alto rendimento e un'elevata percentuale delle migliori parti della carcassa (petto, coscia, sovraccoscia). Nei campioni di carne di cappone sottoposti ad analisi chimica è stata accertata la presenza d'acqua al 71,94\%, di proteine al 19,76\%, di grassi al 6,67\% e di cenere all'1,20\%, mentre tra gli acidi grassi hanno prevalso gli oleici (40,74\%), i palmitici (30,15\%) e gli stearici (11,30\%).

Parole chiave: carne del cappone, rendimento della macellazione, composizione chimica di base, profilo degli acidi grassi

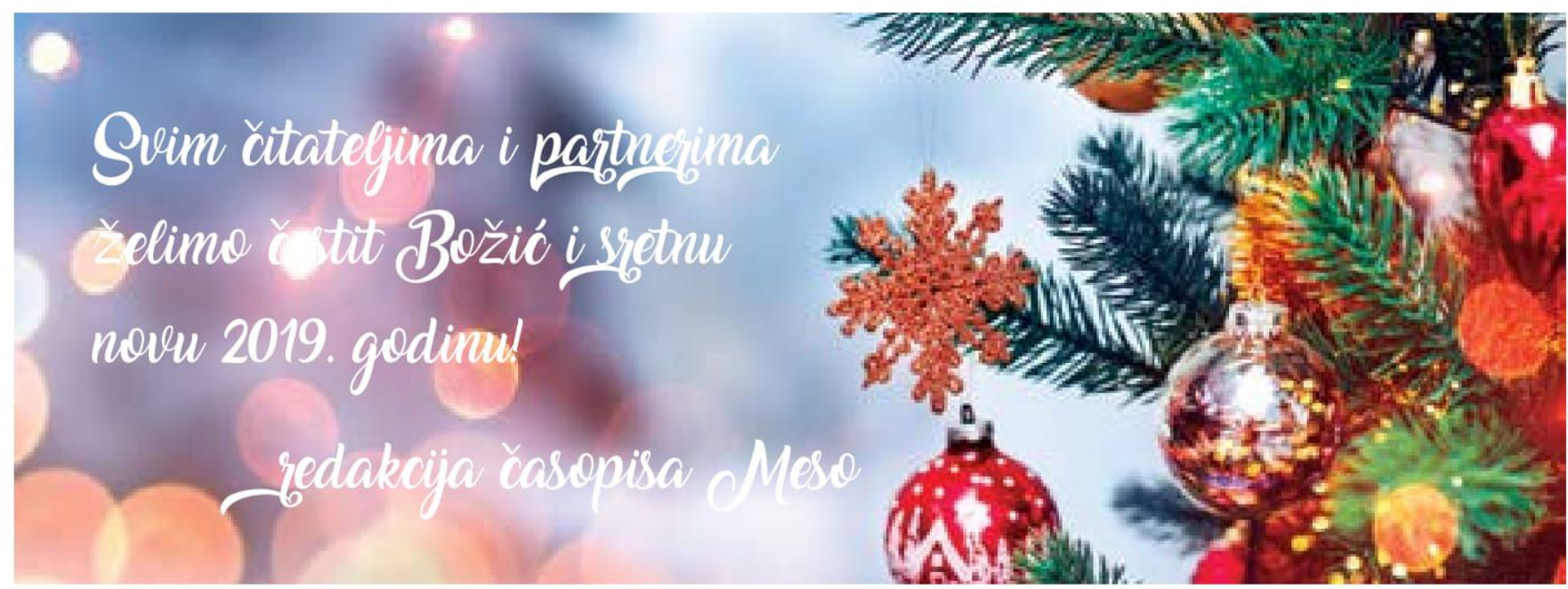

